\title{
Natural dynamics and thinning response of young lenga (Nothofagus pumilio) trees in secondary forests of Southern Patagonia
}

\author{
Dinámica natural y respuesta al raleo de árboles juveniles de lenga (Nothofagus pumilio) \\ en bosques secundarios en Patagonia Sur
}

\author{
Pablo L Peri a,b,c*, Guillermo Martínez Pastur ${ }^{\text {c,d }}$, Lucas Monelos ${ }^{\text {b }}$ \\ *Autor de correspondencia: ${ }^{a}$ Instituto Nacional de Tecnología Agropecuaria (INTA), cc 332 (CP 9400), \\ Río Gallegos, Santa Cruz, Argentina, tel./fax: +54-2966-442305, peri.pablo@inta.gob.ar \\ ${ }^{\mathrm{b}}$ Universidad Nacional de la Patagonia Austral (UNPA), Argentina. \\ ${ }^{\mathrm{c}}$ Consejo Nacional de Investigaciones Científicas y Técnicas (CONICET), Argentina. \\ ${ }^{\mathrm{d}}$ Centro Austral de Investigaciones Científicas (CADIC), Argentina.
}

\begin{abstract}
SUMMARY
For saw-log production, planned thinning in secondary forests may reduce the time to yield products of a desired size and quality. To explore some options, long-term monitoring plots were established in 1996 in two secondary stands of Nothofagus pumilio (19,300 stems ha-1, age 34 years and 18,300 stems ha-1, age 40 years) in Santa Cruz province, Argentina. The study quantified growth responses to different thinning intensities around crop trees in the understory stratum of a two-aged stand, and growth dynamics in a natural unthinned stand regenerated by strip clearcutting. For the analysis of natural dynamics, growth, mortality and shift of crown classes of all trees were measured annually during 10 years. For thinning, 1,111 crop trees per hectare were selected. Thinning consisted of four intensities: elimination of one (T1), two (T2) and all (Tt) effective competitors, and a control (Tc). Each treatment was replicated ten times in a split plot design, where the main plots in this two-aged stand were three different levels of canopy covered by the remaining overstory seed trees $(0,12$ and $33 \%)$. The stand dynamics among unthinned plots revealed that competition-induced mortality occurred at a mean rate of 680 trees ha $^{-1}$ year $^{-1}$ (3.5 \% of all trees) and mean growth rate of $7.2 \mathrm{~m}^{3}$ ha $^{-1}$ year ${ }^{-1}$. Ten-year results from the thinned plots indicated a significant difference in the growth response of crop trees among treatments; being higher for Tt and T2, and under $12 \%$ canopy cover. Thinning also reduced windthrow because it removed only the effective competitors and maintained a high stocking among crop trees. That offered mutual protection within the understory stratum.
\end{abstract}

Key words: crown class dynamic, mortality rate, stability, silviculture.

\section{RESUMEN}

Para producir trozas aserrables, los raleos planificados en bosques secundarios podrían reducir el tiempo requerido para obtener productos de tamaño y calidad deseados para la industria. En este sentido, en 1996 fueron establecidas parcelas permanentes en dos rodales coetáneos de Nothofagus pumilio (19.300 árboles ha-1 ${ }^{-1}$ edad 34 años y 18.300 árboles ha ${ }^{-1}$, edad 40 años) en la provincia de Santa Cruz, Argentina. El objetivo del presente estudio fue cuantificar el crecimiento en respuesta a diferentes raleos en el estrato juvenil inferior de rodales de dos clases de edad, y compararlos con el crecimiento de rodales bajo dinámica natural regenerados a partir de tala rasa en fajas. Para el análisis de la dinámica natural, anualmente se midió crecimiento, mortalidad y tasa de pasaje de clases de copa de todos los árboles durante 10 años. En las parcelas de raleo fueron seleccionados 1.111 árboles futuros por hectárea. Fueron consideradas cuatro intensidades de raleo: eliminación de un (T1), dos (T2) y todos (Tt) los competidores efectivos de los árboles seleccionados, y un control. Cada tratamiento fue replicado diez veces en diseño de parcelas divididas (parcelas principales: tres niveles de cobertura del dosel superior de árboles semilleros; 0, 12 y 33 \%). Con dinámica natural, la mortalidad por competencia ocurrió a una tasa media de 680 árboles ha-1 año-1 (3,5\% del total de árboles) con crecimiento medio de 7,2 $\mathrm{m}^{3}$ ha $^{-1}$ año-1. Los resultados luego de diez años, con raleo, indicaron diferencias significativas en el crecimiento entre tratamientos: mayor en Tt y T2 bajo $12 \%$ de cobertura de copas. Los raleos de baja intensidad redujeron caída de árboles por viento, porque solo eliminaron competidores efectivos, lo cual mantuvo alta densidad del rodal que protegió a los árboles seleccionados.

Palabras clave: dinámica de clases de copa, tasa de mortalidad, estabilidad, silvicultura.

\section{INTRODUCTION}

Nothofagus pumilio (Poepp. et Endl.) Krasser (lenga) is the most important native timber species of southern $\mathrm{Pa}-$ tagonia; both in Chile and Argentina. Large areas of this species have been harvested over the last 120 years, with natural regeneration successfully established as a result (Peri et al. 2002, Gea et al. 2004). The most common silviculture has been a uniform shelterwood system with a 100 -year rotation and a 20 -year regeneration period. This 
mimics natural forest dynamics associated with large canopy gaps and provides satisfactory ecological conditions for regeneration of a new cohort (Martínez Pastur et al. 1999). In general, the regeneration phase is characterized by a high density of trees per hectare, high competition rates and a high mortality due to inter-tree competition (Martínez Pastur et al. 2001). Growth of young trees after seed cutting can be affected by the degree of overstory canopy openness and the resulting understory light intensity. Martínez Pastur et al. (2011) reported optimum height growth of lenga regeneration at light intensity associated with intermediate canopy cover.

For saw-log production, planned thinning in secondary forest stands may reduce the time required to yield products of a desired quality, concentrate growth on selected trees and increase long-term yields by utilizing trees that would die in the absence of thinning. Intermediate treatment schedules and thinning trials for lenga have been reported previously (Grosse 1987, Nuñez and Vera 1992, Schmidt et al. 1995, 1996, Martínez Pastur et al. 2001, Peri et al. 2002). However, among some lenga forests in Patagonia, wind damage and wind-throw are common across large areas. This affects the resulting stand structure (Veblen et al. 1996). Since 1998, nearly 5,000 ha of these lenga forests have been blown down in Tierra del Fuego province (Argentina) alone (Collado 2011).

Losses and other damage by winds may affect the success of a silvicultural treatment such as thinning (Peri et al. 2002). Some evidence suggests that low intensity thinning practices that eliminate only effective competitors not only prevent coarse-scale wind-throw, but also reduce the negative visual impact of managed forests and meet other forest management objectives such as improving stand growth and quality.

The research reported here investigated the responses after different intensities of thinning (crop tree release) among young lenga trees in the understory stratum of twoaged stands having different degrees of canopy cover of older seed trees left after shelterwood seed cutting. It also evaluated the natural dynamics and tree growth in unmanaged young stands regenerated by strip clearcutting. We hypothesized that growth response after crop tree release on these dry sites would be higher among trees growing under protection of the residual seed trees due to the effect of partial shading in reducing water stress.

\section{METHODS}

Study area. One set of research plots was established in 1996 in two-aged stands of lenga forest in Santa Cruz province ( $51^{\circ} 34^{\prime} \mathrm{S}, 72^{\circ} 01^{\prime} \mathrm{W}$ ), Argentina. Sixty hectares of the stand have seed trees (> 150 years) remaining after shelterwood seed cutting 40 years earlier (Peri and Rial 2003).The stand has a site index of $9.8 \mathrm{~m}$ at base age 60 years $\left(\mathrm{SI}_{60}=9.8 \mathrm{~m}\right)$. The landscape is classified as cold temperate and subhumid, with long-term annual average air temperature of $4.5^{\circ} \mathrm{C}$, annual precipitation of $488 \mathrm{~mm}$ and potential evaporation in excess of $950 \mathrm{~mm}_{\text {year }}{ }^{-1}$. The predominant wind direction is from south-southwest. Severe and frequent windstorms occur in spring and summer, with wind speeds over $120 \mathrm{~km} \mathrm{~h}^{-1}$. Soils are coarse textured and classified as Mollisols. Based on thirty bulked soil sample cores taken at random at 0-30 $\mathrm{cm}$ in depth (corresponding to main root distribution), they present: $\mathrm{pH} 4.9$; organic carbon $4.7 \%$; total nitrogen $0.42 \%$; available phosphorus 132 $\mathrm{mg} \mathrm{kg}^{-1}$; and a sandy loam texture (USDA) with $47 \%$ sand, $7 \%$ clay and $46 \%$ silt.

Unmanaged stand dynamic plots. A separate 60 ha portion in the same area had been regenerated by $500 \mathrm{~m}$ wide strip clearcutting during 1950-60. Within this $34 \pm 4$ year-old area of even-aged lenga we installed two circular $100 \mathrm{~m}^{2}$ plots. The stand had 19,300 stems ha-1 ${ }^{-1}$ with a mean diameter at breast height (DBH) of $5.4 \mathrm{~cm}$. In these plots there are no remaining seed trees. Mortality, DBH and crown classes were recorded annually for each tree in the plots during 10 years since plots were established. Total volume over bark (TVOB) was calculated using a local equation reported by Peri (1995) and fitted for the same study area. We used these plots to represent unmanaged even-aged stands and to assess natural dynamics of secondary lenga.

Thinning treatments plots. Thinning plots were located in a two-aged area having a younger understory stratum (age 40 \pm 5 years, mean DBH $7.02 \mathrm{~cm}$ ) and three different levels of canopy covered by older residual seed trees $(0,12$ and $33 \%$ ). In this area we used a split plot design to establish three $1,440 \mathrm{~m}^{2}$ overstory main plots; each having smaller 36 $\mathrm{m}^{2}$ subplots used for thinning the younger understory stratum. Treatments included releasing crop trees (dominants, straight stems and good health) by eliminating one, two, all or no effective competitors (T1, T2, Tt and Tc, respectively). An effective competitor was defined as any dominant or codominant tree with a crown touching that of the crop tree (figure 1). Altogether we released an equivalent of 1,111 crop trees ha-1 and replicated the treatments 10 times. The range of stand density of younger understory stratum before and after the application of four thinning treatments is shown in table 1 .

\section{RESULTS}

Unmanaged stand dynamics. At the beginning of the 10year research period, the stand regenerated by strip clearcutting had a mean DBH of $5.4 \mathrm{~cm}$, with $36 \%$ of stems in the $3-5 \mathrm{~cm}$ class, $27 \%$ in the $5-7 \mathrm{~cm}$ class, $22 \%$ in the 7-9 $\mathrm{cm}$ class and $15 \%$ with more than $9 \mathrm{~cm}$ (maximum DBH of $15 \mathrm{~cm}$ ). Stand density decreased from 19,300 trees ha $^{-1}$ in 1996 to 12,500 trees ha-1 in 2006 (figure 2). This revealed that the competition-induced mortality occurred at a mean rate of 680 trees $^{-1} \mathrm{year}^{-1}$ (minimum and maximum values were 250 and 1,750 trees ha ${ }^{-1}$ year $\left.^{-1}\right)$. Mortality 


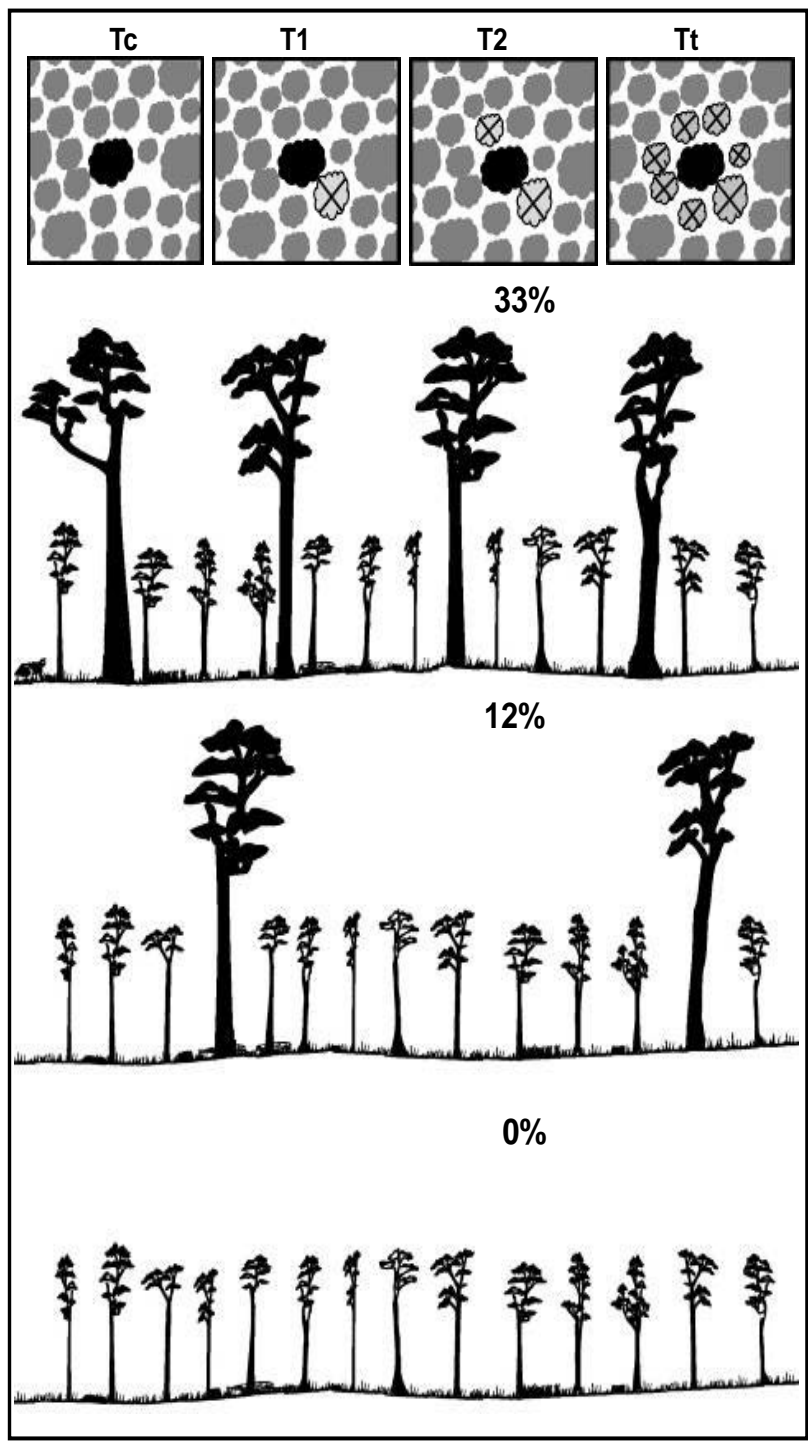

Figure 1. Diagram of the thinning plots carried out in a two-aged Nothofagus pumilio area having a younger age class (18,500 stems $\mathrm{ha}^{-1}$, age 40 years). The three larger figures represent the main plots with three different levels of canopy covered by older residual seed trees $(0,12$ and $33 \%)$. The top four figures represent the subplots with the crop tree release treatments: elimination of one, two and all effective competitors (T1, T2 and Tt, respectively) and the control (Tc). The tree shown in black indicates one of the selected 1,111 crop trees ha-1.

Diagrama del ensayo de raleo realizado en bosques secundarios coetáneos de Nothofagus pumilio (18.500 árboles hä-1, edad 40 años) con un diseño de parcelas divididas, donde las parcelas principales fueron tres niveles de cobertura del dosel superior de árboles semilleros (0, 12 y $33 \%)$ y las parcelas secundarias fueron cuatro intensidades: eliminación de un (T1), dos (T2) y todos (Tt) los competidores efectivos de los árboles seleccionados, y un control (Tc). Los árboles señalados con color negro (parte superior) representan uno de los 1.111 árboles futuros seleccionados. was confined to diameter classes $(1-4 \mathrm{~cm})$ corresponding to intermediate and overtopped (suppressed) trees. Also, a shift of crown class categories occurred over time due to competition (figure 3). The proportion of dominant and codominant trees decreased from 26 and $24 \%$ in 1996 to 14 and $12 \%$ in 2006, respectively. Overtopped trees increased $26 \%$ during the same period.

During the ten years, the mean DBH increased from 5.4 to $7.1 \mathrm{~cm}$; at a weighted (by the proportion of crown classes in the stand) average growth rate of $0.08 \mathrm{~cm}_{\text {year }}{ }^{-1}$ (figure 4). However, the mean growth rate differed among crown classes, with a mean annual DBH increment of 0.22, $0.12,0.09$ and $0.02 \mathrm{~cm}_{\text {year }}{ }^{-1}$ for dominant, codominant, intermediate and overtopped trees, respectively (data not shown).

Stand BA increased from 51.7 in 1996 to $59.0 \mathrm{~m}^{2} \mathrm{ha}^{-1}$ in 2006 at a mean growth rate of $0.73 \mathrm{~m}^{2} \mathrm{ha}^{-1}$ year ${ }^{-1}$ (figure 4). The total mean volume increment ranged from 4.2 to 11.0 $\mathrm{m}^{3} \mathrm{ha}^{-1}$ year ${ }^{-1}$ with an average of $7.2 \mathrm{~m}^{3} \mathrm{ha}^{-1}$ year ${ }^{-1}$ (figure 4). However, $57 \%$ of this was attributed to growth of dominant crown class alone (24\% of the trees).

Thinning treatments. Ten-year results showed significant differences in the growth response of crop trees both due to the thinning treatments and between levels of overstory canopy cover (table 2). The mean change in DBH, BA and total volume outside bark was higher for the treatment that eliminated all (Tt) or two (T2) competitors, and under $12 \%$ remnant canopy cover (table 2). However, there was an interaction between canopy cover and thinning treatments over time (table 2, figure 5). For example, total over-bark volume growth rate was higher for T1 and Tt beneath $12 \%$ remnant canopy cover, but higher for T2 under 33 \% cover of the remnant overstory trees (figure 5). Overall, maximum DBH, BA and total over-bark volume growth rates were registered for trees in treatment $\mathrm{T} 2$ and grown beneath $33 \%$ canopy cover $\left(0.35 \mathrm{~cm}_{\text {year }}^{-1} ; 0.49 \mathrm{~m}^{2}\right.$ ha $^{-1}$ year ${ }^{-1}$ and $4.7 \mathrm{~m}^{3} \mathrm{ha}^{-1}$ year $\left.^{-1}\right)$. The minimum mean growth occurred in plots with $0 \%$ canopy and no thinning (Tc) $(0.11 \mathrm{~cm}$ year-1; $0.14 \mathrm{~m}^{2}$ ha $^{-1}$ year $^{-1}$ and $0.95 \mathrm{~m}^{3} \mathrm{ha}^{-1}$ year $^{-1}$ ). There was no wind-throwing in any thinning plot during the period of study (1996-2006).

\section{DISCUSSION}

Results from unthinned stand dynamic plots indicated that competition-induced mortality averaged 680 trees ha $^{-1}$ year $^{-1}$, which represents an annual mortality rate of $3.5 \%$ for the 10-year period evaluated. For secondary forests, the main cause of mortality for semi-shade tolerant lenga (Martínez Pastur et al. 2007) is mainly light competition among individuals (Peri and Arce 1998). This is consistent with Wardle (1984), who reported on the annual mortality of about 3-5\% of all stems in even-aged red beech (Nothofagus fusca) and mountain beech (Nothofagus solandrivar. cliffortioides) stands up to 90 years old in New Zealand. 
Table 1. Mean stand density ( \pm standard deviation) of younger understory stratum (stems ha ${ }^{-1}$ ) before and after the application of four thinning treatments and three levels of remnant seed tree canopy cover (0,12 and 33 \%) in Santa Cruz province, Argentina.

Densidad media del estrato inferior de los rodales (árboles ha $^{-1} \pm$ desviación estándar) antes y después de la aplicación de cuatro tratamientos de raleo y tres niveles de cobertura de copas (0,12 y 33 \%), en la provincia de santa Cruz, Argentina.

\begin{tabular}{cccc}
\hline Canopy cover & Thinning treatments & Before thinning & After thinning \\
\hline $0 \%$ & 0 (control) & $19,890 \pm 680$ & $19,890 \pm 680$ \\
& $\mathrm{~T} 1$ & $20,110 \pm 810$ & $18,990 \pm 760$ \\
$\mathrm{~T} 2$ & $19,560 \pm 740$ & $17,340 \pm 660$ \\
$\mathrm{Tt}$ & $19,180 \pm 620$ & $15,180 \pm 490$ \\
\hline $12 \%$ & 0 (control) & $17,850 \pm 380$ & $17,850 \pm 380$ \\
& $\mathrm{~T} 1$ & $18,130 \pm 620$ & $17,020 \pm 580$ \\
& $\mathrm{~T} 2$ & $17,980 \pm 470$ & $15,760 \pm 410$ \\
$\mathrm{Tt}$ & $18,050 \pm 590$ & $14,160 \pm 460$ \\
\hline $33 \%$ & 0 (control) & $17,230 \pm 410$ & $17,230 \pm 410$ \\
& $\mathrm{~T} 1$ & $16,840 \pm 350$ & $15,730 \pm 320$ \\
& $\mathrm{~T} 2$ & $17,750 \pm 520$ & $15,528 \pm 450$ \\
& $\mathrm{Tt}$ & $16,950 \pm 310$ & $13,060 \pm 240$ \\
\hline
\end{tabular}

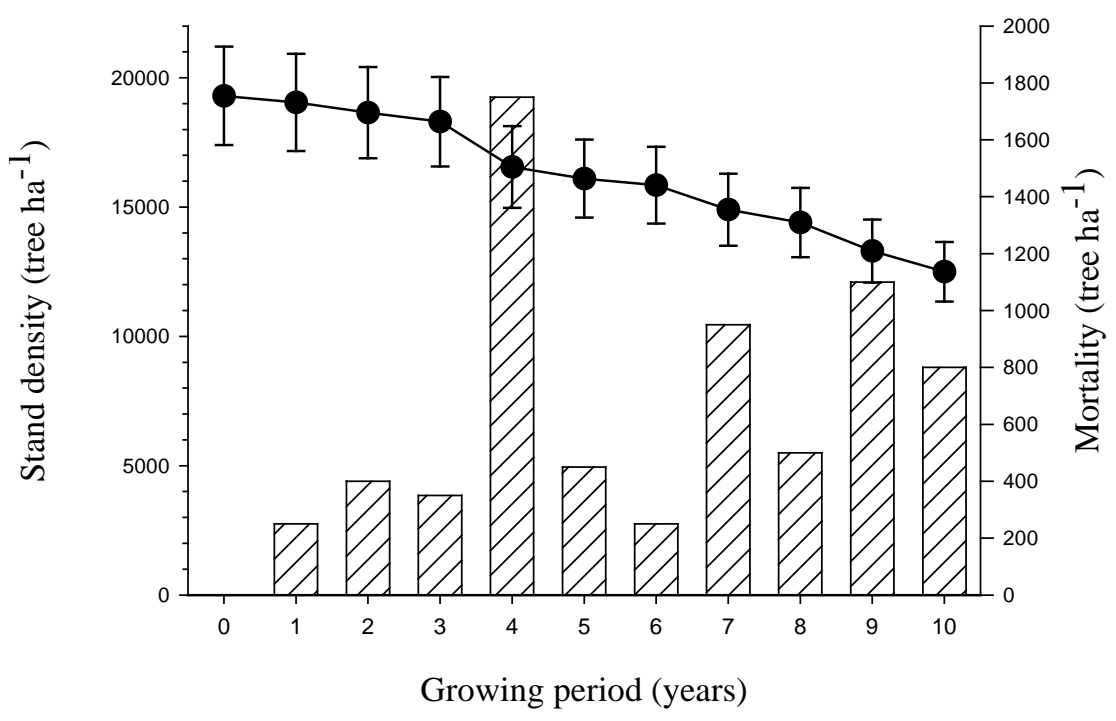

Figure 2. Stand density (black dots) and mortality (bars) within intermediate-aged (34 \pm 4 years after strip clearcutting) Nothofagus pumilio growing at a site index of $9.8 \mathrm{~m}$ at base age 60 years $\left(\mathrm{SI}_{60}=9.8 \mathrm{~m}\right)$, Santa Cruz province, Argentina. Bars indicate standard error of the mean (sem).

Dinámica de la densidad de rodal (círculos negros) y mortalidad (barras) para bosques de edad intermedia (34 \pm 4 años) de Nothofagus pumilio creciendo en una calidad de sitio de 9,8 $\mathrm{m}$ a la edad base de 60 años $\left(\mathrm{IS}_{60}=9,8 \mathrm{~m}\right.$ ), provincia de Santa Cruz, Argentina.

The mortality in our stands was higher than that reported by Peri et al. (2002) for older (67 years old) even-aged N. pumilio stands $\left(18-22\right.$ trees ha ${ }^{-1}$ year $\left.^{-1}\right)$ on a better site $\left(\mathrm{SI}_{60}=23.2 \mathrm{~m}\right)$ and with lower initial stem density $(2,382 \pm$ 770). This reinforces the notion that mortality differs with stand age and site quality.

The mean growth rate within the unthinned plots (0.73 $\mathrm{m}^{2}$ ha $^{-1}$ year ${ }^{-1} \mathrm{BA} ; 7.2 \mathrm{~m}^{3}$ ha $^{-1}$ year ${ }^{-1}$ total volume over bark) showed the important contribution of dominant trees. The mean annual DBH rate was 0.22 and $0.02 \mathrm{~cm}_{\text {year }}{ }^{-1}$ for dominant and overtopped trees, respectively, and $57 \%$ of the total mean volume increment occurred within the dominant crown class. This importance of upper-canopy trees to stand-level production has been reported previously (Peri and Martínez Pastur 1996, Martínez Pastur et al. 2002, Martínez Pastur et al. 2005). 


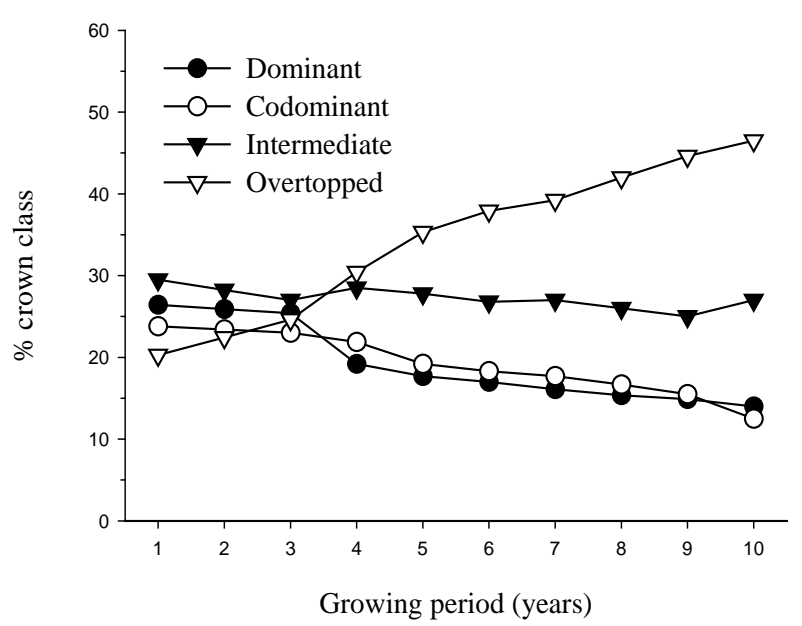

Figure 3. Shift in crown classes categories occurred over time for intermediate-aged (34 \pm 4 years after strip clearcutting) Nothofagus pumilio stand growing at $\mathrm{SI}_{60}=9.8 \mathrm{~m}$, Santa Cruz province, Argentina.

Traspaso de clases de copa en función del tiempo en bosques de edad intermedia (34 \pm 4 años) de Nothofagus pumilio creciendo en una calidad de sitio de $9,8 \mathrm{~m}$ a la edad base de 60 años $\left(\mathrm{IS}_{60}=9,8 \mathrm{~m}\right.$ ), provincia de Santa Cruz, Argentina.

The thinning plots indicated that removing all (Tt) and two (T2) competitors increased the change of mean DBH, BA and total volume outside bark by approximately 27, 31 , and $39 \%$, respectively, compared to no thinning. These rates were lower than those reported by Peri et al. (2002), where volume growth increased by $83 \%$ (light thinning) and $65 \%$ (heavy thinning) for a pure $N$. pumilio forests (67 years) growing in a high quality site $\left(\mathrm{SI}_{60}=23.2 \mathrm{~m}\right.$ ), and the maximum growth of $12.7 \mathrm{~m}^{3} \mathrm{ha}^{-1}$ year ${ }^{-1}$ reported by Martínez Pastur et al. (2001) for pure N. pumilio stands grown in site quality II-III (mean dominant height of 22$26 \mathrm{~m}$ ). Such findings highlight the benefit of establishing permanent plots representing different thinning treatments (intensity) across a site quality gradient in order to fully reveal the potential growth responses within lenga stands.

In our study, there was an effect of remnant overstory trees on thinning responses. Maximum DBH, BA and total over-bark volume growth responses were registered for trees growing under some protection of an overstory canopy, and the minimum mean growth occurred on plots lacking remnant seed trees in the superior strata. Similarly, Martínez Pastur et al. (2011) reported a superior height growth of $N$. pumilio regeneration beneath the protection of older residual seed trees (45 \% crown cover). According to Peri et al. (2009) and Martínez Pastur et al. (2007), $N$. pumilio seedlings have higher photosynthetic rates in big gaps or when light availability increases due to silvicultural treatments, and when water is non-limiting. However, when soil moisture becomes a limiting environmental factor (pre-dawn leaf water potential less than -1.7 MPa), the photosynthetic response (and therefore growth) is reduced regardless of light availability. Apparently, partial protection by the remaining seed trees at our study site (corresponding to a low site quality and where desiccating strong winds are frequent) interacts with light availability by affecting soil water conditions. However, Peri and Arce (1998) reported that the growth of regeneration varied with the combined effects of neighborhood competition and the remnant overstory trees density.

The thinning system proposed for lenga by the present work reduced the probability of windthrow (no wind-thrown trees were registered during the 10 -year period) because it
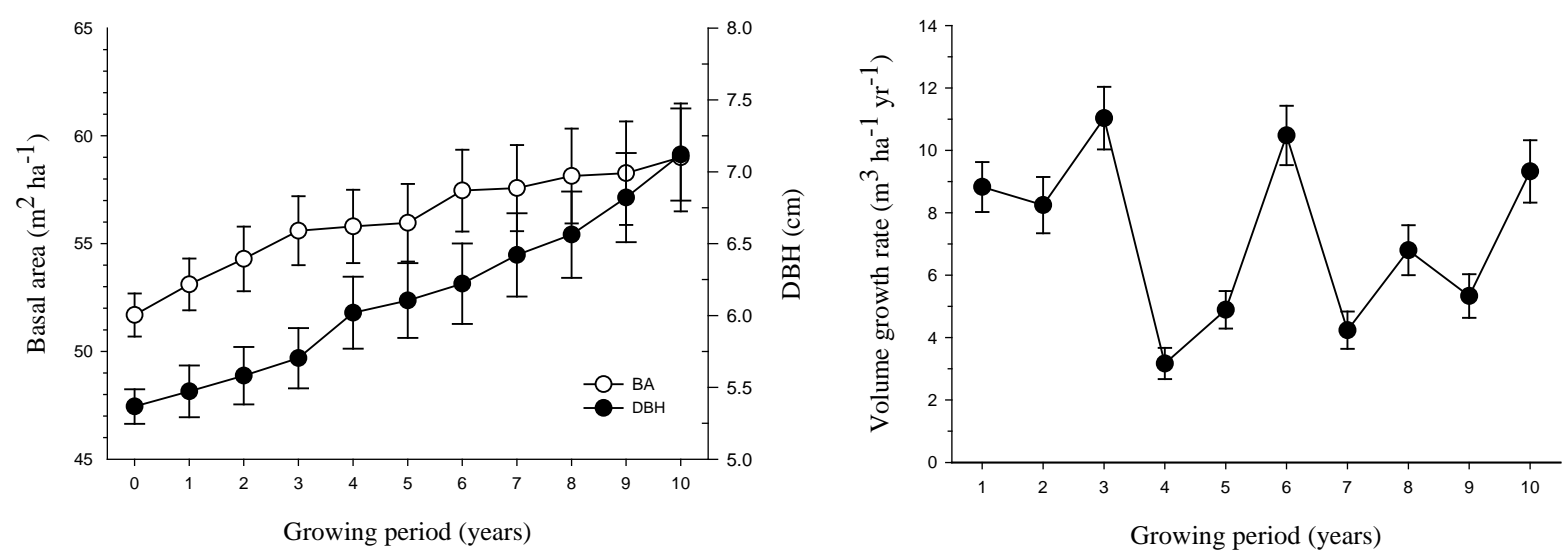

Figure 4. Basal area, tree diameter (DBH) development, and total over-bark volume (TOBV) growth dynamics for an intermediate-aged (34 \pm 4 years after strip clearcutting) Nothofagus pumilio unmanaged stand growing at a site index of $9.8 \mathrm{~m}$ at base age 60 years $\left(\mathrm{SI}_{60}=9.8 \mathrm{~m}\right)$, Santa Cruz province, Argentina. Bars indicate standard error of the mean $(\mathrm{sem})$.

Desarrollo del área basal (AB) y diámetro a la altura del pecho (DAP), y tasa de crecimiento del volumen total con corteza (VTCC) de los 1.111 árboles seleccionados en bosques de edad intermedia ( $40 \pm 5$ años) de Nothofagus pumilio creciendo en una calidad de sitio de $9,8 \mathrm{~m}$ a la edad base de 60 años $\left(\mathrm{IS}_{60}=9,8 \mathrm{~m}\right)$, provincia de Santa Cruz, Argentina. 
Table 2. Mean 10-year growth (1996-2006) for diameter at breast height (DBH), basal area (BA) and total over-bark volume (TOBV) for 1,111 intermediate-aged ( $40 \pm 5$ years) Nothofagus pumilio crop trees after four thinning treatments and beneath three levels of remnant seed tree canopy cover (0,12 and $33 \%)$ in Santa Cruz province, Argentina.

Tasa media de crecimiento (período de 10 años, 1996-2006) en diámetro a la altura del pecho (DAP), área basal (AB) y volumen total con corteza (VTCC) de los 1.111 árboles seleccionados en bosques de edad intermedia (40 \pm 5 años) de Nothofagus pumilio para un período de 10 años (1996-2006) correspondiente a cuatro tratamientos de raleo (eliminación de 1, 2 y todos los competidores efectivos y el control) creciendo bajo tres diferentes cobertura del dosel superior de árboles semilleros (0, 12 y 33 \%) en la provincia de Santa Cruz, Argentina.

\begin{tabular}{cccc}
\hline Thinning treatments & $\begin{array}{c}\mathrm{DBH} \\
\left(\mathrm{cm} \mathrm{year}^{-1}\right)\end{array}$ & $\begin{array}{c}\text { BA } \\
\left(\mathrm{m}^{2} \mathrm{ha}^{-1} \mathrm{year}^{-1}\right)\end{array}$ & $\begin{array}{c}\text { TOBV } \\
\left(\mathrm{m}^{3} \mathrm{ha}^{-1} \mathrm{year}^{-1}\right)\end{array}$ \\
\hline 0 (control) & $0.16 \mathrm{a}$ & $0.24 \mathrm{a}$ & $1.46 \mathrm{a}$ \\
$\mathrm{T} 1$ & $0.17 \mathrm{a}$ & $0.27 \mathrm{a}$ & $2.72 \mathrm{a}$ \\
$\mathrm{T} 2$ & $0.21 \mathrm{~b}$ & $0.34 \mathrm{~b} \mathrm{~b}$ & $2.39 \mathrm{~b}$ \\
$\mathrm{Tt}$ & $0.22 \mathrm{~b}$ & $0.36 \mathrm{~b}$ & $1.50 \mathrm{a}$ \\
Canopy cover & & & $2.16 \mathrm{~b}$ \\
$12 \%$ & $0.18 \mathrm{a}$ & $0.25 \mathrm{a}$ & $2.13 \mathrm{ab}$ \\
33 $\%$ & $0.22 \mathrm{~b}$ & $0.34 \mathrm{~b}$ & $* .32 \mathrm{ab}$ \\
Thinning effect & $0.20 \mathrm{ab}$ & $* * *$ & $* *$ \\
Canopy cover effect & $* *$ & $*$ & $* *$ \\
Interaction & $*$ & $* *$ & $* *$ \\
\hline
\end{tabular}

ns $=$ non significant; $*=P<0.05 ; * *=P<0.01 ; * * *=P<0.001$. Different lower-case letters indicate significant differences among levels of each factor (thinning treatment and canopy cover).
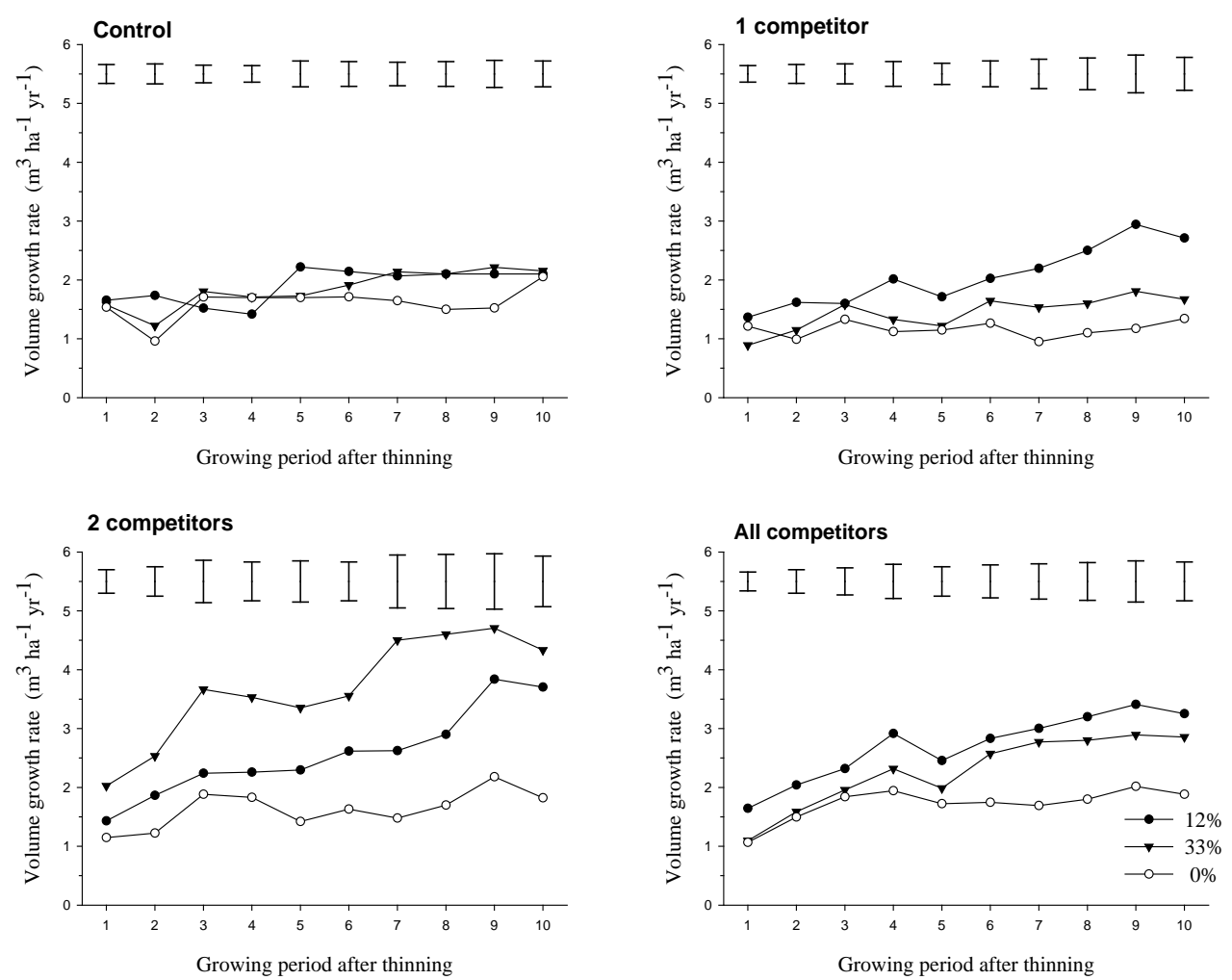

Figure 5. Total over-bark volume (TOBV) growth over 10 years (1996-2006) after four thinning treatments and beneath three levels of remnant seed tree canopy cover for 1,111 Nothofagus pumilio crop trees ha ${ }^{-1}$ of intermediate-aged (40 \pm 5 years) growing at a SI ${ }_{60}=$ $9.8 \mathrm{~m}$, Santa Cruz province, Argentina. Bars indicate standard error of the mean (sem).

Tasa de crecimiento del volumen total con corteza (VTCC) para un período de 10 años (1996-2006) de los 1.111 árboles seleccionados correspondiente a cuatro tratamientos de raleo (eliminación de 1, 2 y todos los competidores efectivos y el control) creciendo bajo tres diferentes cobertura del dosel superior de árboles semilleros (0, 12 y 33 \%) en bosques de edad intermedia (40 \pm 5 años) de Nothofagus pumilio creciendo en una calidad de sitio de 9,8 $\mathrm{m}$ a la edad base de 60 años $\left(\mathrm{IS}_{60}=9,8 \mathrm{~m}\right)$, provincia de Santa Cruz, Argentina. 
removed only the effective competitors and maintained a high stocking among the crop trees. That afforded mutual protection for the trees in the understory stratum. Also, this low-intensity thinning allows foresters to make repeated cuts over the whole area on a shorter cutting cycle, and it doesn't affect the scenic values because the crop tree release removes only a limited portion of the stand each time. Our long-term plots will provide essential data for developing a future computer-based model to assist forest management planning cultural treatments for Nothofagus spp. stands in Patagonia. In addition these long-term plots will eventually allow us to define base-lines and impacts for different thinning treatments and provide a demonstration of effects from forest management. Also, these plots provide areas to be used for training professionals in forest management practices.

\section{REFERENCES}

Collado L. 2011. Situación de estado, disponibilidad y posibilidad de aprovechamiento de los bosques de lenga de Tierra del Fuego. Informe Dirección General de Bosques, Secretaría de Desarrollo Sustentable y Ambiente de Tierra del Fuego. 18 p.

Gea G, G Martínez Pastur, JM Cellini, MV Lencinas. 2004. Forty years of silvicultural management in southern Nothofagus pumilio (Poepp. et Endl.) Krasser primary forests. Forest Ecology and Management 201: 335-347.

Groose H. 1987. Desarrollo de renovales de raulí raleados. Ciencia e Investigación Forestal 1(2): 31-43.

Martínez Pastur G, PL Peri, C Fernández, G Staffieri, D Rodríguez. 1999. Desarrollo de la regeneración a lo largo del ciclo del manejo forestal de un bosque de Nothofagus pumilio: 1. Incidencia de la cobertura y el aprovechamiento. Bosque 20 (2): 39-46.

Martínez Pastur G, JM Cellini, MV Lencinas, R Vukasovic, R Vicente, F Bertolami, J Giunchi. 2001. Modificación del crecimiento y de la calidad de fustes en un raleo fuerte de un rodal en fase de crecimiento óptimo inicial de Nothofagus pumilio (Poepp. et Endl.) Krasser. Ecología Austral 11: 95-104.

Martínez Pastur G, JM Cellini, MV Lencinas, B Díaz, PL Peri, R Vukasovic. 2002. Funciones de rendimiento volumétrico en pie y en aserradero para la Lenga (Nothofagus pumilio). Ciencias Forestales 15(1-2): 32-45.

Martínez Pastur G, JM Cellini, PL Peri, I Capiel. 2005. Ecuación estándar de crecimiento diamétrico individual para árboles de Nothofagus pumilio. Revista de la Asociación Forestal Argentina 1: 17-25.

Martínez Pastur G, MV Lencinas, PL Peri, M Arena. 2007. Photosynthetic plasticity of Nothofagus pumilio seedlings to light intensity and soil moisture. Forest Ecology and Management 243: 274-282.

Martínez Pastur G, PL Peri, JM Cellini, MV Lencinas, M Barrera, H Ivancich. 2011. Canopy structure analysis for estimating forest regeneration dynamics and growth in Nothofagus pumilio forests. Annals of Forest Sciences 68: 587-594.

Nuñez P, O Vera. 1992. Evaluación de intervenciones silvícolas en un renoval mixto de lenga (Nothofagus pumilio) y coihue (Nothofagus dombeyi), ubicado en la reserva forestal Coyaique, XI Región. Publicación Técnica CIEFAP 8: 111-125.

O’Brien RA. 1989. Comparison of overstory canopy cover estimates on forest survey plots. Ogden, UT, USA. USDA Forest Service, Research Paper INT-417. 5 p.

Peri PL. 1995. Ecuaciones de volumen bruto, neto y de corteza para Lenga (Nothofagus pumilio) en Ea. Stag-River, Santa Cruz. Publicación Técnica Forestal N 5 Convenio UNPAINTA-CAP. 14 p.

Peri PL, G Martínez Pastur. 1996. Crecimiento diamétrico de Nothofagus pumilio para dos condiciones de copa en un sitio de calidad media de Santa Cruz (Argentina). Investigación Agraria: Sistemas y Recursos Forestales 5(2): 201-212.

Peri PL, J Arce. 1998. Estudio estructural de la regeneración avanzada de Lenga (Nothofagus pumilio) en Patagonia Sur, Argentina. In Actas Primer Congreso Latinoamericano de IUFRO. Tema 3 (47): Manejo, Protección y Conservación de Bosques Naturales. Valdivia, Chile. 22-28 de Noviembre de 1998.

Peri PL, G Martínez Pastur, R Vukasovic, B Díaz, MV Lencinas, JM Cellini. 2002. Thinning schedules to reduce risk of windthrow in Nothofagus pumilio forests of Patagonia, Argentina. Bosque 23(2): 19-28.

Peri PL, P Rial. 2003. Inventario forestal en bosques de Nothofagus en Patagonia Sur (Argentina) utilizando imágenes satelitales. Forestalia 8: 60-69.

Peri PL, G Martínez Pastur. MV Lencinas. 2009. Photosynthetic response to different light intensities and water status of two main Nothofagus species of southern Patagonian forest, Argentina. Journal of Forest Science 55(3): 101-111.

Schmidt H, J Caldentey, S Donoso. 1995. Informe: Investigación sobre el manejo de la lenga - XII Región. Santiago, Chile. Universidad de Chile - CONAF. 40 p.

Schmidt H, J Caldentey, S Donoso, K Peña. 1996. Informe: Seguimiento forestal y ambiental del uso de los bosques de lenga XII Región. Santiago, Chile. Universidad de Chile - CONAF. $37 \mathrm{p}$.

Veblen TT, C Donoso, T Kitzberger, AJ Rebertus. 1996. Ecology of southern Chilean and Argentinean Nothofagus forests. In Veblen TT, RS Hill, J Read eds. The Ecology and Biogeography of Nothofagus Forests. New Haven, Yale University Press. p. 293-353.

Wardle J. 1984. The New Zealand Beeches: Ecology, Utilization and Management. Christchurch, New Zealand. New Zealand Forest Service. 447 p. 
